\title{
Mouse zygotes as recipients in embryo cloning
}

\author{
Paweł Gręda, Jolanta Karasiewicz and Jacek A Modliński \\ Department of Experimental Embryology, Institute of Genetics and Animal Breeding, Polish Academy of Sciences, \\ Jastrzębiec, 05-552 Wólka Kosowska, Poland
}

Correspondence should be addressed to J A Modliński; Email: j.a.modlinski@ighz.pl

\begin{abstract}
Zygotes have not been recognized as nuclear recipients since enucleated zygotes receiving nuclei from beyond two-cell stage embryos are not able to form blastocysts. In the present study, a new technique of zygote enucleation is presented, which consists in selectively removing the nuclear membrane with genetic material of pronuclei, but leaving other pronuclear components in the cytoplasm. With selective enucleation it is possible - after transfer of eight-cell stage nuclei - to obtain 70.5 and $7.8 \%$ of preimplantation and full-term development respectively. Origin of cloned mice from introduced nuclei was confirmed by the coat colour and glucose phosphate isomerase (GPI) isozyme of the donor. We suggest that some pronuclear factors - taken away from the zygotes in the karyoplasts upon classical enucleation - are needed to reprogram the introduced nuclei.
\end{abstract}

Reproduction (2006) $132741-748$

\section{Introduction}

The first evidence that embryonic nuclei introduced into zygotes can persist in developing embryos was achieved almost 30 years ago when Modliński (1978) microsurgically introduced mouse eight-cell stage nuclei of the CBA/H T6T6 strain into intact zygotes and showed the presence of two T6 marker chromosomes in resulting tetraploid blastocysts. Three years later, Illmensee \& Hoppe (1981) reported successful mouse cloning via microsurgical injection of inner cell mass (ICM) nuclei into microsurgically enucleated zygotes. However, this result has never been repeated. McGrath \& Solter (1984) transferred mouse embryonic nuclei from the preimplantation stages into enucleated zygotes and drew a conclusion of the 'inability of mouse blastomere nuclei transferred in enucleated zygotes to support development in vitro'. Nevertheless, attempts followed to clone mammals from zygotes reconstituted either with embryonic or embryonic stem (ES) cell nuclei (mouse, Robl et al. 1986, Howlett et al. 1987, Tsunoda et al. 1987, Smith et al. 1988, Cheong et al. 1992, Wakayama et al. 2000; rat, Kono et al. 1988; rabbit, Modliński \& Smorąg 1991; pig, Prather et al. 1989; cattle, Prather \& First 1990; rhesus, Meng et al. 1997). In all cases, the reconstituted zygotes were able to develop only when early two-cell stage nuclei had been transferred. The developmental abilities of more advanced embryonic nuclei were severely limited; in the overwhelming majority of cases they were not able to support development of reconstituted zygotes beyond the first two cleavage divisions. These failures to produce mammals from reconstituted zygotes culminated in the final conclusion of Wakayama et al. (2000) - following Solter's (1999) reply to Illmensee's letter (1999) - 'that there is no firm reason for Hineinienterpretierung of the claim of mouse cloning using zygotes'.

However, it should be indicated that in all cloning experiments since 1983, zygotes have been enucleated using the method of McGrath \& Solter (1983), in which karyoplasts containing intact pronuclei are removed (CE, complete enucleation). Thus, we have developed an alternative method of enucleation of interphase cells based on the technique described earlier (Modliński 1975), which allows the removal of the pronuclear envelope of with attached chromatin and to leave the pronuclear contents in the zygote's cytoplasm (SE, selective enucleation).

\section{Materials and Methods}

All inorganic and organic compounds were purchased from Sigma unless otherwise stated.

\section{Collection of zygotes and embryos}

Mature $(\mathrm{C} 57 \mathrm{BI} 10 \times \mathrm{CBA} / \mathrm{H}) \mathrm{F} 1, \mathrm{DBA} / 2$ and $\mathrm{CBA} / \mathrm{H} \mathrm{T} 6 \mathrm{~T} 6$ mice approximately 3 months old originated from our own colony. They were kept in a temperature-controlled room with a $12 \mathrm{~h}$ light: $12 \mathrm{~h}$ darkness cycle (lights on 
from 0600 to $1800 \mathrm{~h}$ ). Food (Labofeed H, Kcynia, Poland; metabolic energy of $13.0 \mathrm{MJ} / \mathrm{kg}$ ) and water were available ad libitum. Donor females were killed by cervical dislocation. Recipient females and males that were subjected to vasectomy were anaesthetized by i.p. injection of $0.15-0.20 \mathrm{ml}$ (depending on body weight) of 0.75\% pentobarbital (Vetbutal, Biovet Puławy, Poland).

Female $(\mathrm{C} 57 \mathrm{BI} \times \mathrm{CBA} / \mathrm{H}) \mathrm{F} 1$ mice were superovulated by injection of $7.5 \mathrm{IU}$ pregnant mare serum gonadotrophin (Folligon, Intervet, Holland) followed by $7.5 \mathrm{IU}$ human chorionic gonadotrophin (hCG; Chorulon, Intervet, Holland) 48-52 $\mathrm{h}$ later and mated with F1 males. Zygotes were collected from the oviducts 18-20 h after hCG injection and were devoid of cumulus cells by treatment with hyaluronidase $(150 \mathrm{IU} / \mathrm{ml} \mathrm{PBS})$, washed three times in M2 medium and then cultured in KSOM medium ( $\mathrm{KCl}$-enriched simplex optimized medium; Specialty Media, Phillipsburg, NJ, USA) at $37^{\circ} \mathrm{C}(5 \%$ $\mathrm{CO}_{2}$ in air) until both pronuclei became clearly visible. Prior to enucleation, zygotes were preincubated for 2030 min in M2 medium with the addition of cytochalasin $\mathrm{B}(\mathrm{CB}, 5 \mu \mathrm{g} / \mathrm{ml})$ and nocodazole $(0.25 \mu \mathrm{g} / \mathrm{ml})$.

Eight-cell embryos collected from spontaneously ovulated DBA/2 and CBA/H T6T6 females mated with $\mathrm{DBA} / 2$ and $\mathrm{CBA} / \mathrm{H}$ T6T6 males respectively were used as donors of nuclei. Embryos were flushed from oviducts and tubo-uterine junctions around noon on the third day after mating (vaginal plug, day 1). Zonae pellucidae were removed from eight-cell embryos by treatment with $0.5 \%$ pronase in PBS for 3-5 min (Mintz 1962). After rinsing the embryos in three changes of M2 medium, they were transferred to Dulbecco's salt solution, which was devoid of $\mathrm{Ca}$ and $\mathrm{Mg}$ ions, for $15 \mathrm{~min}$. After this treatment, the embryos were pipetted with a flame-polished narrow-bore pipette in M2 medium to disaggregate them into single blastomeres. Before micromanipulation, the isolated blastomeres were incubated in $\mathrm{M} 2$ medium supplemented with CB $(5 \mu \mathrm{g} / \mathrm{ml})$ for 20-30 min.

The experiments were performed according to the rules of the Polish Governmental Act for Animal Care and were approved (No. 33/2003) by the III Local Ethics Committee for Animal Care at Warsaw Agricultural University.

\section{Selective enucleation (SE) of zygotes}

Micromanipulations were performed under inverted Leitz Fluovert microscope equipped with Nomarski DIC and Leitz mechanical micromanipulators. Preincubated zygotes were placed in the drop of the same incubation medium under paraffin oil in a micromanipulation chamber. A conical pipette with the diameter of $1-2 \mu \mathrm{m}$ at its tip was used for enucleation. This pipette was introduced in the vicinity of an early/mid-pronucleus and, by applying strong negative pressure the nuclear envelope was adhered to the tip of the pipette (Fig. 1). Upon withdrawing the pipette from the zygote,

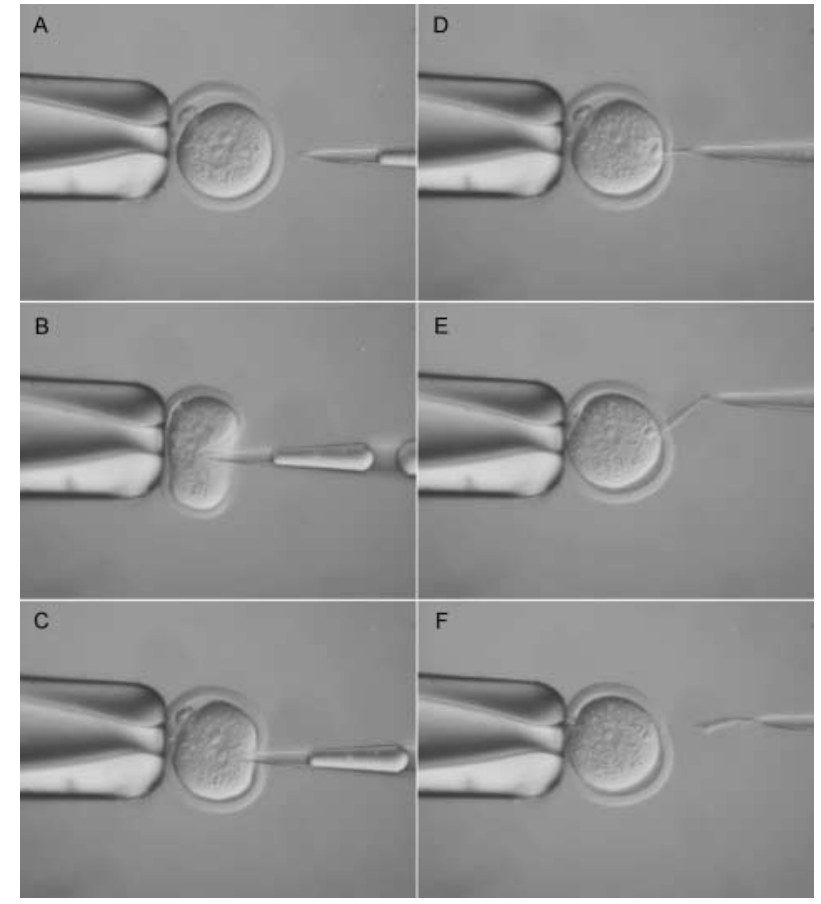

Figure 1 Selective enucleation of a mouse zygote: (A) a conical pipette with a diameter of 1-2 $\mu \mathrm{m}$ at its tip approaches the zygote; two apposed pronuclei - each with a nucleolus - visible in the zygote cytoplasm; (B) puncturing zona pellucida to enter the cytoplasm; (C) applying negative pressure to the nuclear envelope of the lower pronucleus; (D) withdrawing the pipette from the zygote and, simultaneously, pulling out the nuclear envelope; $(E)$ the pronucleus tears open, releasing its contents into the cytoplasm; (F) the nuclear envelope, with chromatin attached to it, is removed from the zygote; nucleolus remains in the cytoplasm. The second pronucleus will be later removed from this zygote in the same way.

the pronucleus tears open due to increase in its internal pressure and the nuclear envelope, with the attached chromatin network (see Fig. 2 for Hoechst stained pronuclei), is removed. The liquid pronuclear contents and nucleoli remain in the cytoplasm. The second pronucleus is removed in the same way.

\section{Complete enucleation (CE) of zygotes}

Complete enucleation was performed using the standard enucleation technique of McGrath \& Solter (1983).

\section{Zygote-blastomere fusion}

Enucleated zygotes were placed with isolated blastomeres in $\mathrm{M} 2$ medium $+\mathrm{CB}(5 \mu \mathrm{g} / \mathrm{ml})$ and a single blastomere was introduced under the zona pellucida into the perivitelline space. The pairs of cells were washed three times in CB-free M2 medium and exposed to electric pulses (Kubiak \& Tarkowski 1985). Electrofusion was performed in $0.3 \mathrm{M}$ mannitol supplemented with $0.1 \mathrm{mM} \mathrm{MgSO}_{4}$ and $0.05 \mathrm{mM} \mathrm{CaCl}_{2}$ using Electrocell Manipulator ECM 2001 (BTX Gentronics, San Diego, CA, 


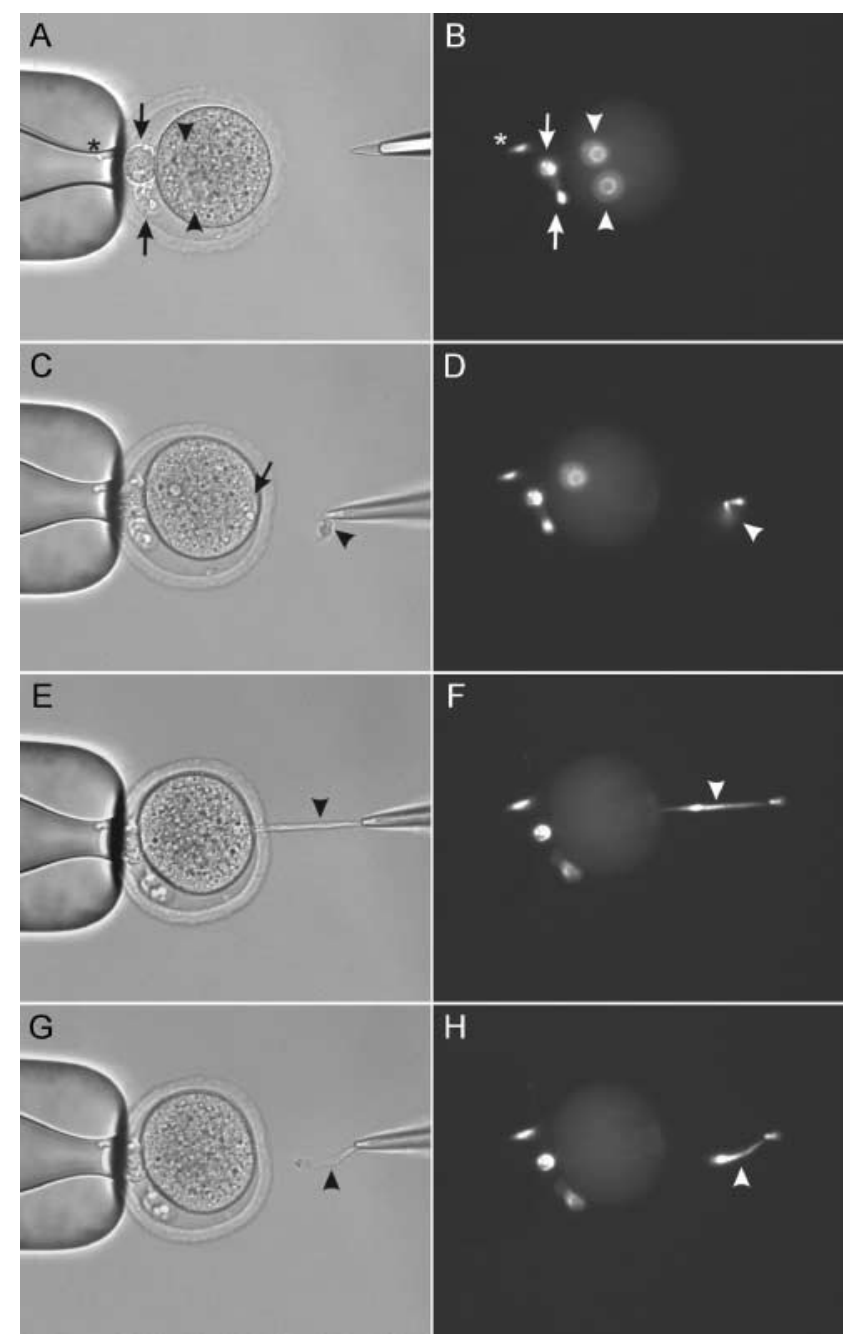

Figure 2 Selective enucleation of a mouse zygote stained with Hoechst stain $(4 \mu \mathrm{g} / \mathrm{ml})$ to follow DNA removal. (A) and (B) Two pronuclei (arrowheads) and the nuclei of polar bodies (arrows) are visible; an asterisk $(*)$ points to an unessential artefact; (C) and (D) after removal of the first pronucleus, nucleoli (arrow) and no residual fluorescence are visible in the cytoplasm; the pronucleus attached to the tip of the micropipette is highly fluorescent (arrowhead); $(\mathrm{E})-(\mathrm{H})$ after removal of the second pronucleus no residual fluorescence remains in the cytoplasm; the pronucleus attached to the tip of the micropipette is highly fluorescent (arrowhead).
USA) in the BTX 453 fusion chamber. Two direct current (DC) pulses $(1.2 \mathrm{kV} / \mathrm{cm})$ of $55 \mu \mathrm{s}$ each were applied. Treated pairs were rinsed three times in M2 medium, incubated in $\mathrm{M} 2$ at $37.5^{\circ} \mathrm{C}$ and monitored for fusions.

\section{Culture in vitro and in vivo}

The fused pairs were washed three times in the prewarmed $\mathrm{KSOM}$ medium and placed in $\mathrm{KSOM}$ for culture $\left(37.5{ }^{\circ} \mathrm{C}, 5 \% \mathrm{CO}_{2}\right.$ in air). Reconstituted zygotes were either cultured in vitro for 5 days or cultured 2-4 days to be transferred (as two- to eight-cell embryos) into pseudopregnant Swiss albino females mated with proved vasectomized Swiss albino males.

\section{Electrophoretic and karyological analysis}

Blood samples were frozen in small amount of redistilled water and samples of tissues/organs were frozen in Trisglycine buffer; all were stored at $-20{ }^{\circ} \mathrm{C}$. Before electrophoresis, the samples were thawed and frozen thrice, and supernatant was applied to the plates. Electrophoresis was performed on cellulose acetate plates (Titan III H, Helena Biosciences, Gateshead, UK) as described by Buehr \& McLaren (1985), with minor modifications.

Chromosome preparations were made of blastocysts using air-drying method (Tarkowski 1966) and stained with Giemsa stain.

\section{Results}

The efficiency of selective enucleation (Figs 1 and 2) is given in Table 1. Out of 268 zygotes reconstructed using DBA2 blastomeres, $240(89.5 \%)$ survived the double enucleation. In zygotes reconstructed with $\mathrm{CBA} / \mathrm{H}$ T6T6 blastomere nuclei, the efficiency was $82.8 \%$. As it is shown in Fig. 2, during selective enucleation the chromatin (DNA) is removed along with pronuclear envelope. In the overwhelming majority of cases all nucleoli were left in the zygote cytoplasm. In a small proportion of SE zygotes, one or two smallest nucleoli were removed along with the pronuclear envelope.

Table 1 Enucleation of mouse zygotes and their reconstruction with eight-cell blastomere nuclei.

\begin{tabular}{llclll}
\hline $\begin{array}{l}\text { Blastomere strain } \\
\text { of mice }\end{array}$ & Enucleation & $\begin{array}{c}\text { No. of enucleated } \\
\text { zygotes }\end{array}$ & $\begin{array}{l}\text { No. of surviving } \\
\text { zygotes }(\%)\end{array}$ & $\begin{array}{l}\text { No. of zygote/ } \\
\text { blastomere pairs }\end{array}$ & No. of fused pairs \\
\hline DBA2 & $\mathrm{SE}^{\mathrm{a}}$ & 118 & 103 & 89 & 85 \\
DBA2 & $\mathrm{SE}^{\mathrm{b}}$ & 150 & 137 & 133 & 129 \\
Total & & 268 & $240(89.5)$ & $222(82.8)$ & $214(79.8)$ \\
CBA/H T6T6 & $\mathrm{SE}^{\mathrm{a}}$ & 28 & 22 & 20 & 20 \\
CBA/H T6T6 & $\mathrm{SE}^{\mathrm{b}}$ & 65 & 55 & 53 & 51 \\
Total & $\mathrm{CE}$ & 93 & $77(82.8)$ & $73(78.5)$ & $71(76.3)$ \\
CBA/H T6T6 & $\mathrm{CE}$ & 49 & $47(95.9)$ & $47(95.9)$ & $42(85.7)$ \\
\hline
\end{tabular}

$\mathrm{SE}$, selective enucleation; $\mathrm{CE}$, complete enucleation.

${ }^{\mathrm{a}}$ For blastocysts. ${ }^{\mathrm{b}}$ For transfer to recipients. 
Table 2 In vitro development of enucleated zygotes reconstituted with 1/8 blastomeres.

\begin{tabular}{|c|c|c|c|c|c|c|c|}
\hline \multirow[b]{2}{*}{$\begin{array}{l}\text { Strain of } \\
\text { blastomeres }\end{array}$} & \multirow[b]{2}{*}{$\begin{array}{l}\text { Type of } \\
\text { enucleation }\end{array}$} & \multicolumn{6}{|c|}{ No. of development up to (\%) } \\
\hline & & Two-cell day 2 & Four-cell day 3 & Eight-cell day 4 & Morula day 5 & Blastocyst day 5 & Total \\
\hline DBA2 & $\mathrm{SE}^{\mathrm{a}}$ & $81 / 85(95.3)$ & $64 / 85(75.3)$ & $61 / 85(71.7)$ & 20/85 (23.5) & $40 / 85(47)$ & 85 \\
\hline DBA2 & $\mathrm{SE}^{\mathrm{b}}$ & $38 / 40(95)$ & $39 / 89$ (43.8) & $33 / 89(37.1)$ & n.d. & n.d. & 129 \\
\hline CBA/H T6T6 & $\mathrm{SE}^{\mathrm{a}}$ & n.o. & n.o. & n.o. & $10 / 20(50)$ & $6 / 20(30)$ & 20 \\
\hline CBA/H T6T6 & $\mathrm{SE}^{\mathrm{b}}$ & $12 / 12(100)$ & $20 / 39(51.3)$ & $18 / 39(46.2)$ & n.d. & n.d. & 51 \\
\hline $\mathrm{CBA} / \mathrm{H}$ T6T6 & $C E^{a}$ & $22 / 42(52.3)$ & $1 / 42(2.4)$ & $0 / 42$ & $0 / 42$ & $0 / 42$ & 42 \\
\hline
\end{tabular}

SE, selective enucleation; CE, complete enucleation; n.d., not done; n.o., no observation.

${ }^{\mathrm{a}}$ For blastocysts. ${ }^{\mathrm{b}}$ For transfer to recipients.

Nucleoli which remained in the cytoplasm usually integrated immediately into a single structure.

Out of 222 selectively enucleated zygotes injected with eight-cell DBA2 blastomeres, 214 (96.4\%) fused. Out of them, 85 were cultured in vitro for 5 days and another 129 SE reconstituted zygotes were cultured in vitro for differing duration (up to 4 days) to be transferred to recipient females for postimplantation development.

Out of 73 selectively enucleated zygotes injected with an eight-cell CBA/H T6T6 blastomere, 71 (97.3\%) fused. Out of them, 20 were cultured in vitro for 5 days and another 51 SE reconstituted zygotes were cultured in vitro for differing duration (up to 4 days) to be transferred to recipient females for postimplantation development. Of the 47 completely enucleated zygotes injected with eight-cell CBA/H T6T6 blastomeres, 42 $(89.4 \%)$ fused. All of them were cultured in vitro for 5 days. Out of 85 SE zygotes reconstituted with DBA2 blastomeres and cultured in vitro for 5 days, 20 and 40 developed to compacted morula and blastocyst stages respectively (Table 2). Dynamics of cleavage in this group is also shown in Table 2. Out of 20 SE zygotes reconstituted with $\mathrm{CBA} / \mathrm{H}$ T6T6 blastomeres and cultured in vitro for 5 days, ten and six developed to compacted morula and blastocyst stages respectively (Table 2).

Three groups of zygotes were fused with CBA/H T6T6 eight-cell blastomeres, carrying a small marker T6 chromosome, thus providing a tool to karyologically prove the origin of developing reconstituted embryos. The same strain of blastomeres was used for reconstitution of completely enucleated zygotes. Indeed, when $\mathrm{CBA} / \mathrm{H}$ T6T6 nuclei were injected into selectively enucleated zygotes, the blastocysts carrying two T6 marker chromosomes were produced (Fig. 3). No development beyond four-cell stage was obtained after transfer of $\mathrm{CBA} / \mathrm{H}$ T6T6 eight-cell nuclei into 42 completely enucleated zygotes.

Out of 129 embryos developed from SE zygotes reconstituted with DBA2 nuclei and cultured in vitro to be later transferred to foster mothers, 77 (38 two-cell, 6 four-cell and 33 eight-cell embryos) were transferred into nine recipients at the first day of pseudopregnancy
(Table 3). Four of them became pregnant and six young $(7.8 \%)$ were obtained. Since the first born pup was eaten by the recipient, the remaining five (two females and three males) were delivered by Caesarean section and fed by foster mothers. Their coat colour indicated the DBA/2 origin (Fig. 4) which was also confirmed by the electrophoretic separation of glucose phosphate isomerase (GPI) isozymes (Fig. 5). One male, upon sexual maturation, proved to be fertile. Out of 32 embryos developed from SE zygotes reconstituted with $\mathrm{CBA} / \mathrm{H}$ T6T6 nuclei and transferred to four recipient females, only one implantation site was found upon Caesarean section at day 20.

\section{Discussion}

Full-term development was obtained after the transfer of embryonic nuclei into telophase I and anaphase II

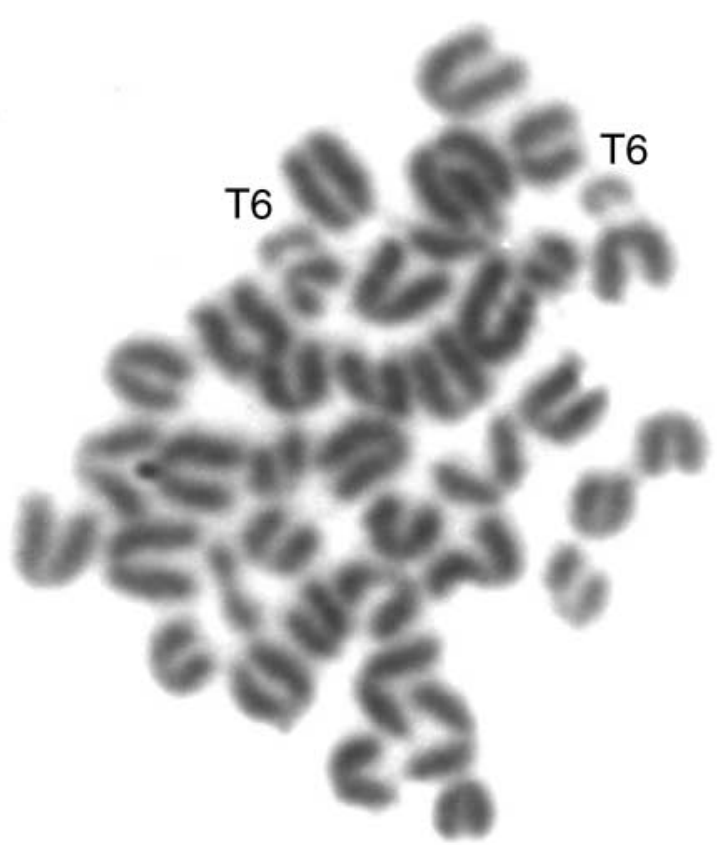

Figure 3 Chromosome spread from a cloned mouse blastocyst. F1 $(\mathrm{C} 57 \mathrm{BL} / 6 \times \mathrm{CBA} / \mathrm{H})$ zygote was reconstructed with $\mathrm{CBA} / \mathrm{H}$ T6T6 1/8 blastomere nucleus. The smallest 2 of the 40 chromosomes present are T6 marker chromosomes. 
Table 3 In vivo development of enucleated zygotes reconstituted with 1/8 blastomeres.

\begin{tabular}{lccccc}
\hline Strain of mice & Enucleation & No. of recipients & $\begin{array}{c}\text { No. of transferred } \\
\text { embryos }\end{array}$ & $\begin{array}{c}\text { No. of pregnant } \\
\text { recipients }\end{array}$ & No. of young born (\%) \\
\hline DBA2 & SE & 9 & 77 & 4 & $6(7.8)$ \\
CBA/H T6T6 & SE & 4 & 32 & 1 & $0^{\mathrm{a}}$ \\
\hline
\end{tabular}

$\mathrm{SE}$, selective enucleation.

${ }^{\mathrm{a} O n e}$ empty implantation site was found upon Caesarean section at day 20.

oocytes (Kono et al. 1992) and into two-cell blastomeres (mouse, Tsunoda et al. 1987, Kono \& Tsunoda 1989, Kono et al. 1991, rat, Roh et al. 2003), as well as after the transfer of somatic nuclei into telophase II oocytes (cow, Bordignon \& Smith 1998, Liu et al. 2000; goat, Baguishi et al. 1999) and two-cell embryos (rabbit, Skrzyszowska et al. 2006). However, in almost all cloning procedures performed during the last 20 years, metaphase II oocytes were the cytoplasts of choice.

Zygotes are not recognized as nuclear recipients on the basis that enucleated zygotes receiving nuclei from beyond two-cell stage are unable to progress through more than 2-3 cleavages. However, tetraploid embryos produced by transfer of eight-cell and ICM cell nuclei into non-enucleated zygotes can give rise to blastocysts (Modliński 1978, 1981). In addition, haploid zygotes reconstituted with haploid eight-cell nuclei of the opposite parental origin can develop into live young (Surani et al. 1986). When diploid eight-cell nuclei were introduced into recipient zygotes that retained either the male or the female pronucleus, blastocysts were produced (Howlett et al. 1987). However, when the resident pronucleus was removed (even as late as $5 \mathrm{~h}$ after nuclear transfer) or silenced with either transcriptional inhibitor or DNA synthesis inhibitor, no development beyond two-cell stage followed (Howlett et al. 1987). These observations suggest 'an active and continued helper role of the resident pronucleus for the participation of eight-cell nucleus in reconstituted eggs' (Howlett et al. 1987). The question arises what the mechanism of such helper action is.

In Xenopus, the remodelling of introduced somatic nuclei is much more evident in an egg than in an oocyte cytoplasm. However, if the germinal vesicle (GV) is ruptured prior to nuclear transfer - which would allow the mix of GV material with the oocyte cytoplasm - the efficiency of remodelling increases significantly (Gurdon 1968, 1976, Gurdon et al. 1979). Also, recent studies concerning the nuclear transfer into germinal vesicle mouse oocytes indicate that GV material is essential for nuclear remodelling (Gao et al. 2002, Cheong et al. 2004). This suggests that both in amphibians and mammals, the nuclear components released from germinal vesicle may play an important role to facilitate remodelling and reprogramming of the introduced foreign nuclei. Moreover, it is suggested that some of the GV components released into the cytoplasm of the oocyte after GVBD, appear to be incorporated - after oocyte activation - into growing pronuclei (Polanski et al. 2005). The nature of these components remains unknown, but the results obtained from the earlier amphibian studies suggest that the possible candidates, which could be involved in remodelling of foreign nuclei are such molecules as nucleoplasmin (Laskey et al. 1978) and N1/N2 nuclear proteins (Kleinschmidt et al. 1986).

The first overt event, interpreted as morphological evidence of remodelling of the introduced nucleus, is nuclear swelling. Furthermore, this nuclear enlargement is probably a conditio sine qua non for successful nuclear reprogramming (Gurdon 1976, Czołowska et al. 1984, Tani et al. 2003). The amphibian studies indicated that it could be the result of a considerable movement of cytoplasmic proteins into the nucleus (Merriam 1969, Barry \& Merriam 1972). In the mouse, the specific examples of oocyte-made karyophilic materials that could flow into the nucleus are nuclear lamins (Kubiak et al. 1991) and snRNA and snRNPs (Dean et al. 1989), which are exhausted from the cytoplasm shortly after oocyte activation. If the cytoplasmic components essential for successful development are incorporated into growing pronuclei, then the removal of the whole pronuclei by the 'classical' method of enucleation (CE) may lead to depletion of those factors resulting in the low development of reconstructed embryos (Campbell \& Albeiro 2004). One cannot exclude that some of those

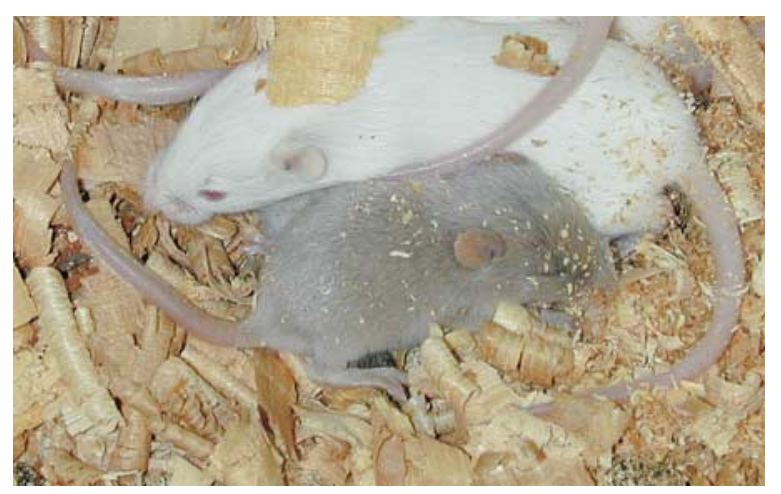

Figure 4 A mouse cloned from a reconstructed zygote. DBA/2 pup (female) derived from $\mathrm{F} 1(\mathrm{C} 57 \mathrm{BL} / 6 \times \mathrm{CBA} / \mathrm{H})$ zygote reconstructed with DBA/2 1/8 blastomere nucleus. The coat colour of the pup indicates its origin from DBA/2 nucleus. The cloned mouse is accompanied by a Swiss albino foster sibling, 3 days older. 


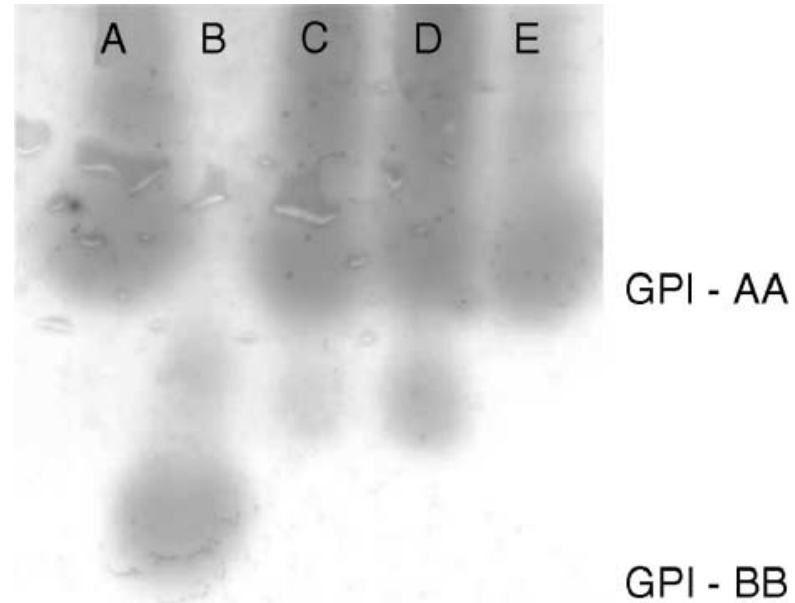

Figure 5 Electrophoretic separation of GPI isozymes. (A) GPI-AA standard (blood of DBA/2 male); (B) GPI-BB standard (blood of F1 $(\mathrm{C} 57 \mathrm{BL} / 6 \times \mathrm{CBA} / \mathrm{H})$ individual); (C) cloned newborn, brain sample; (D) the same cloned newborn, lung sample; (E) 2-month-old cloned male, blood sample.

factors released from pronuclei during the first mitosis remain in the cytoplasm of two-cell stage blastomeres which could explain - to a certain degree - the ability of reconstituted blastomeres for further development.

When the pronuclei are removed using the SE method, the nucleoli remain in the cytoplasm. The nucleolus is a specialized domain of the nucleus in which the production of rRNA and synthesis of ribosomes take place. However, the recent studies revealed that the activity of some cell cycle regulators depends on sequestration in the nucleolus (Olson et al. 2000, 2003, Leung \& Lamond 2003) as well as that nucleoli contain proteins with no known or clear relationship to ribosome biogenesis (Scherl et al. 2002, Politz et al. 2005). One cannot exclude that some of these proteins may enhance, after being released to the cytoplasm, the developmental capabilities of the reconstituted zygotes.

Our results clearly show that usefulness of zygotes as recipients of embryonic nuclei strongly depends on the enucleation method used. In CE method, all nuclear structures and components are taken out from the zygote, while in $\mathrm{SE}$, most likely, only the pronuclear envelope-attached structures are removed. Since there are several lines of evidence that a filamentous scaffold structure underneath the inner nuclear membrane is the anchorage site for chromatin to the nuclear lamina (Marshall et al. 1996, Foisner 2002, Gasser 2002), we believe that - when using SE - the chromatin is being removed along with the pronuclear envelope. The birth of mice entirely derived from the introduced DBA/2 nuclei supports that hypothesis. Perhaps, this explains partially the results of Illmensee \& Hoppe (1981), whose enucleation technique employed narrow pipettes that may have resulted in the removal of the pronuclear envelope and a release of a part of the pronuclear contents back to the cytoplasm.

The efficiency of development to the blastocyst stage of zygotes (our results) and oocytes (Cheong et al. 1993) receiving eight-cell nuclei was the same (47 and $46.2 \%$ respectively) and higher than that obtained after the reconstruction of two-cell blastomeres with eight-cell nuclei (35\%; Tsunoda et al. 1987). This efficiency was also higher than the efficiency of development to the blastocyst stage of oocytes microsurgically injected with nuclei of adult female fibroblast $(38.8 \%)$, thymus $(3.1 \%)$, spleen $(22.4 \%)$, brain $(22.4 \%)$ and Sertoli cells $(39.6 \%$; Wakayama \& Yanagimachi 2001) and also with ES cells nuclei (28.7\%; Wakayama et al. 1999), but lower than in oocytes injected with nuclei of fetal ovarian $(59.3 \%)$ or testicular $(56.4 \%)$ cells and adult male fibroblasts $(59.5 \%)$ or cumulus cells $(53.3 \%$; Wakayama \& Yanagimachi 2001).

According to our best knowledge, the presented results and also those by Cheong et al. (1993) and Hiiragi \& Solter (2005) are the only ones to show that in the mouse obtaining of full-term development is possible after direct transfer of embryonic nuclei from beyond the two-cell stage. In all other cases, live young were produced by serial nuclear transfer (re-cloning) of the nuclei from the NT-derived embryos (obtained after transfer of early stage, morula and ICM/trophectoderm cell nuclei) into enucleated zygotes or two-cell blastomeres (Kwon \& Kono 1996, Tsunoda \& Kato 1997, 1998).

The efficiency of blastocyst formation upon the use of re-cloning procedures is high $-83 \%$ (Kwon \& Kono 1996). The reason why re-cloning is so effective in mice is not clear, but it is speculated that factors present in the cytoplasm of the zygote can enhance the developmental potential of reconstituted embryos (Tsunoda \& Shioda 1988). Indeed, the development to the blastocyst stage was improved significantly (from 16 to $83 \%$ ) when pseudopronuclei from the reconstituted oocytes were introduced into the enucleated zygotes rather than to the activated oocytes (Kwon \& Kono 1996).

The use of zygotes as recipient cells would eliminate the need for activation of reconstituted cytoplasts and simplify the cloning procedures.

\section{Acknowledgements}

This work was supported by grants 2P06D 02626 (J A M and P G) and PBZ-KBN-048/P05/2001/02 (J A M and J K) from the State Committee for Scientific Research. The authors declare that there is no conflict of interest that would prejudice the impartiality of this scientific work. 


\section{References}

Baguishi A, Behboodi E, Melican DT, Pollock JN, Destrempes MM, Cammuso C, Williams JL, Nims SD, Porter CA, Midura P et al. 1999 Production of goats by somatic cell nuclear transfer. Nature Biotechnology 17 456-461.

Barry JM \& Merriam RW 1972 Swelling of hen erythrocyte nuclei in cytoplasm of Xenopus laevis. Experimental Cell Research 71 90-98.

Bordignon V \& Smith LC 1998 Telophase enucleation: an improved method to prepare recipient cytoplast for use in bovine nuclear transfer. Molecular Reproduction and Development 49 29-36.

Buehr M \& McLaren A 1985 Expression of glucose-phosphate isomerase in relation to growth of the mouse oocyte in vivo and in vitro. Gamete Research 11 271-289.

Campbell KHS \& Albeiro R 2004 Nuclear transfer: past, present and future. Animal Science Papers and Reports 22 (Suppl 1) 13-35.

Cheong HT, Takahashi Y \& Kanagawa H 1992 Development of mouse embryonic nuclei transferred to enucleated oocytes and zygotes. Japanese Journal of Veterinary Research 40 149-159.

Cheong HT, Takahashi Y \& Kanagawa H 1993 Birth of mice after transplantation of early-cell stage embryonic nuclei into enucleated oocytes. Biology of Reproduction 48 958-963.

Cheong CC, Nagy ZP, Abdelmassih R, Yang X \& Tian XC 2004 Nuclear and microtubule dynamics of $\mathrm{G} 2 / \mathrm{M}$ somatic nuclei during haploidization in germinal vesicle-stage mouse oocytes. Biology of Reproduction 70 752-758.

Czołowska R, Modliński JA \& Tarkowski AK 1984 Behaviour of thymocyte nuclei in non-acivated and activated mouse oocytes. Journal of Cell Science 69 19-34.

Dean WL, Seufert AC, Schultz GA, Prather RS, Simerly C, Schatten G, Pilch DR \& Marzluff WP 1989 The small nuclear RNAs for premRNA splicing are co-ordinately regulated during oocyte maturation and early embryogenesis in the mouse. Development 106 325-334.

Foisner R 2002 Dynamic connections of nuclear envelope proteins to chromatin matrix. In Dynamics of Nuclear Envelope Assembly in Embryos and Somatic Cells, Ed P Collas. Austin, TX, USA: Landes BioSciences.

Gao S, Gasparini B, McGarry M, Ferrier T, Fletcher J, Harkness L, De Sousa P \& Wilmut I 2002 Germinal vesicle material is essential for nucleus remodeling after nuclear transfer. Biology of Reproduction 67 928-934.

Gasser SM 2002 Visualizing chromatin dynamics in interphase nuclei. Science 296 1412-1416.

Gurdon JB 1968 Changes in somatic nuclei inserted into growing and matured amphibian oocytes. Journal of Embryology and Experimental Morphology 20 401-414.

Gurdon JB 1976 Injected nuclei in frog oocytes: fate, enlargement and chromatin dispersal. Journal of Embryology and Experimental Morphology 36 523-540.

Gurdon JB, Laskey RA, DeRobertis EM \& Partington GA 1979 Reprogramming of transplanted nuclei in amphibia. International Review of Cytology. Supplement 9 161-178.

Hiiragi T \& Solter D 2005 Reprogramming is essential in nuclear transfer. Molecular Reproduction and Development 70 417-421.

Howlett SK, Barton SC \& Surani MAH 1987 Nucleo-cytoplasmic interaction following nuclear transplantation in the mouse embryos. Development 101 915-923.

Illmensee K 1999 Controversy over the cloning of mice. Nature 398 $19-20$.

Illmensee K \& Hoppe PC 1981 Nuclear transplantation in Mus musculus: developmental potential of nuclei from preimplantation embryos. Cell 23 9-18.

Kleinschmidt JA, Dingwall C, Maier G \& Franke WW 1986 Molecular characterization of karyophilic, histone-binding protein: cDNA cloning, amino acid sequence and expression of nuclear protein N1/N2 of Xenopus laevis. EMBO Journal 5 3547-3552.
Kono T \& Tsunoda Y 1989 Development of single blastomeres from four- and eight-cell mouse embryos fused into enucleated half of a two-cell embryos. Gamete Research 22 424-434.

Kono T, Shioda Y \& Tsunoda Y 1988 Nuclear transplantation of rat embryos. Journal of Experimental Zoology 248 303-305.

Kono T, Tsunoda Y \& Nakahara T 1991 Production of identical twin and triplet mice by nuclear transplantation. Journal of Experimental Zoology 257 214-219.

Kono T, Kwon OY, Watanabe T \& Nakahara T 1992 Development of mouse enucleated oocytes receiving a nucleus from different stages of the second cell cycle. Journal of Reproduction and Fertility $\mathbf{9 4}$ 481-487.

Kubiak JZ \& Tarkowski AK 1985 Electrofusion of mouse blastomeres. Experimental Cell Research 157 561-566.

Kubiak JZ, Prather RS, Maul GG \& Schatten G 1991 Cytoplasmic modification of nuclear lamins during pronuclear-like transformation of mouse blastomere nuclei. Mechanisms of Development 35 103-111.

Kwon OY \& Kono T 1996 Production of identical sextuplet mice by transferring metaphase nuclei from four-cell embryos. PNAS 93 13010-13013.

Laskey RA, Honda BM, Mills AP \& Finch TJ 1978 Nucleosomes are assembled by an acidic protein that binds histones and transfers them to DNA. Nature 275 416-420.

Leung AKL \& Lamond Al 2003 The dynamics of the nucleolus. Critical Reviews in Eukaryotic Gene Expression 13 39-54.

Liu JL, Wang MK, Sun QY, Xu Z \& Chen DY 2000 Effect of telophase enucleation on bovine somatic nuclear transfer. Theriogenology $\mathbf{5 4}$ 989-998.

Marshall WF, Dernburg AF, Harmon B, Agard DA \& Sedat JW 1996 Specific interactions of chromatin with nuclear envelope: positional determination within the nucleus in Drosophila melanogaster. Molecular Biology of the Cell 7 825-842.

McGrath J \& Solter D 1983 Nuclear transplantation in the mouse embryo by microsurgery and cell fusion. Science 220 1300-1302.

McGrath J \& Solter D 1984 Inability of mouse blastomere nuclei transferred to enucleted zygotes to support development in vitro. Science 226 1317-1319.

Meng L, Ely JJ, Stouffer RL \& Wolf DP 1997 Rhesus monkey produced by nuclear transfer. Biology of Reproduction 57 454-459.

Merriam RW 1969 Movement of cytoplasmic proteins into nuclei induced to enlarge and initiate DNA or RNA synthesis. Journal of Cell Science 5 333-349.

Mintz B 1962 Experimental study of the developing mammalian egg: removal of the zona pellucida. Science 138 594-595.

Modliński JA 1975 Haploid mouse embryos obtained by microsurgical removal of one pronucleus. Journal of Embryology and Experimental Morphology 33 897-905.

Modliński JA 1978 Transfer of embryonic nuclei to fertilized mouse eggs and development of tetraploid blastocysts. Nature $\mathbf{2 7 3}$ 466-467.

Modliński JA 1981 The fate of inner cell mass and trophectoderm nuclei transplanted to fertilized mouse eggs. Nature 292 342-343.

Modliński JA \& Smorąg Z 1991 Preimplantation development of rabbit embryos after transfer of embryonic nuclei into different cytoplasmic environment. Molecular Reproduction and Development $\mathbf{2 8}$ 361-372.

Olson MOJ, Dundr M \& Szebeni A 2000 The nucleolus: an old factory with unexpected capabilities. Trends in Cell Biology 10 189-196.

Olson MOJ, Hingoriani K \& Szebeni A 2003 Conventional and nonconventional roles of nucleolus. International Review of Cytology 219 199-266.

Polanski Z, Hoffmann S \& Tsurumi C 2005 Oocyte nucleus controls progression through meiotic maturation. Developmental Biology 281 184-195.

Politz JCR, Polena I, Trask I, Bazett-Jones DP \& Pedersen T 2005 A nonribosomal landscape in the nucleolus revealed by stem cell protein nucleostemin. Molecular Biology of the Cell 16 3401-3410. 
Prather RS \& First NL 1990 Cloning embryos by nuclear transfer. Journal of Reproduction and Fertility Supplement 41 125-134.

Prather RS, Sims MM \& First NL 1989 Nuclear transplantation in early pig embryo. Biology of Reproduction 41 414-418.

Robl JM, Gilligan B, Crister ES \& First NL 1986 Nuclear transplantation in mouse embryos: assessment of recipient cell stage. Biology of Reproduction 34 733-739.

Roh S, Guo J, Malakooti N, Morrison JR, Trounson AO \& Du ZT 2003 Birth of rats following nuclear exchange at 2-cell stage. Zygote 11 317-321.

Scherl A, Coute Y, Deon C, Calle K, Kindbeiter K, Sanchez JD, Greco A, Hochstrasser D \& Diaz JJ 2002 Functional proteomic analysis of human nucleolus. Molecular Biology of the Cell 13 4100-4109.

Skrzyszowska M, Smorag Z, Slomski R, Katska-Ksiazkiewicz L, Kalak R, Michalak E, Wielgus K, Lehmann J, Lipinski D, Szalata M et al. 2006 Generation of transgenic rabbits by the novel technique of chimeric somatic cell cloning. Biology of Reproduction 74 1114-1120.

Smith LC, Wilmut I \& Hunter RHF 1988 Influence of cell cycle stage at nuclear transplantation on the development in vitro of mouse embryos. Journal of Reproduction and Fertility 84 619-624.

Solter D 1999 Cloning claims challenged. Nature 39913.

Surani MA, Barton SC \& Norris ML 1986 Nuclear transplantation in the mouse: heritable differences between parental genomes after activation of the embryonic genome. Cell 45 127-136.

Tani T, Kato Y \& Tsunoda Y 2003 Reprogramming of bovine somatic cell nuclei is not directly regulated by maturation promoting factor or mitogen-activated protein kinase activity. Biology of Reproduction 69 1890-1894.

Tarkowski AK 1966 An air-drying method for chromosome preparations from mouse eggs. Cytogenetics 5 394-400.
Tsunoda Y \& Kato Y 1997 Full-term development after transfer of nuclei from 4-cell and compacted morula stage embryos to enucleated oocytes in the mouse. Journal of Experimental Zoology 278 250-254.

Tsunoda Y \& Kato Y 1998 Not only inner cell mass cell nuclei but also trophectoderm nuclei of mouse blastocysts have developmental totipotency. Journal of Reproduction and Fertility 113 181-184.

Tsunoda Y \& Shioda Y 1988 Development of enucleated parthenogenones that received pronuclei or nuclei from fertilized mouse eggs. Gamete Research 21 151-155.

Tsunoda Y, Yasui T, Shioda Y, Nakamura K, Uchida T \& Sugie T 1987 Full-term development of mouse blastomere nuclei transplanted into enucleated two-cell embryos. Journal of Experimental Zoology 242 147-157.

Wakayama T \& Yanagimachi R 2001 Mouse cloning with nucleus donor cells of different age and type. Molecular Reproduction and Development 58 376-383.

Wakayama T, Rodriguez I, Perry ACF, Yanagimachi R \& Mombaerts $\mathbf{P}$ 1999 Mice cloned from embryonic stem cells. PNAS $\mathbf{9 6}$ 14984-14989.

Wakayama T, Tateno H, Mombearts P \& Yanagimachi R 2000 Nuclear transfer into mouse zygotes. Nature Genetics 24 108-109.

Received 29 March 2006

First decision 5 June 2006

Revised manuscript received 20 July 2006

Accepted 7 August 2006 